\title{
Pelatihan Penulisan Judul Dan Introduction Dalam Karya Ilmiah Bagi Mahasiswa
}

\author{
Siti Pratiwi Husain ${ }^{1}$, Sri Desiyani Permata Gani², Dhea Safitri Kurniawati Mohamad ${ }^{3}$ \\ 1,2,3 Jurusan Akuntansi, Fakultas Ekonomi, Universitas Negeri Gorontalo, Jl. Jend. Sudirman No. 6 \\ Kota Gorontalo, Gorontalo 96128, Indonesia ${ }^{1}$ \\ E-mail: pratiwi.husain@ung.ac.id ${ }^{1}$
}

Article History:

Received: 02-11-2021

Revised: 06-11-2021

Accepted: 07-11-2021

Keywords: Title, Introduction, Scientific Paper

\begin{abstract}
:
The problem in this research is students still do not understand when writing scientific papers, in choosing a topic or problem, determining the title of a scientific paper, making an introduction, as well as references or data needed in writing scientific papers. The purpose of this service activity is to increase the knowledge of the participants about the importance of writing scientific papers and to improve the ability of the participants to determine the title and make an introduction properly and correctly according to the guidelines for writing scientific papers. The method used is the method of lectures, discussions and exercises. The results of the service activities show that $85 \%$ of participants who come from students who take part in this training activity can determine the title of the scientific work and prepare an introduction in the scientific work.
\end{abstract}

\section{Pendahuluan}

Mengapa kita harus melakukan karya ilmiah? karena manusia memiliki motivasi atau dorongan dengan rasa keingintahuan tentang bagaimana kenyataannya (fakta). Karya ilmiah merupakan karangan yang memaparkan pendapat, hasil pengamatan, tinjauan dan penelitian dalam bidang tertentu yang disusun menurut metode tertentu dengan sistematika penulisan, bersantun bahasa dan isi yang kebenarannya dapat dipertanggungjawabkan (Lubis dan Rahimah, 2019:1)

Karya ilmiah memberikan dampak yang sangat bermanfaat bagi dunia ilmu pengetahuan, teknologi dan peradaban manusia. Tujuan dari penelitian ilmiah adalah dapat memecahkan permasalahan yang tengah terjadi oleh masyarakat (user) dan bagaimana penelitian ini bisa memberikan nilai praktis dan atau nilai konseptual bagi pengembangan ilmu pengetahuan serta memiliki penelitian ini dapat memberikan manfaat bagi kehidupan masyarakat/ user. Perkembangan ilmu pengetahuan ini adalah hasil dari penelitian-penelitian (research) para ahli sebelumnya (Fatihudin, 2012).

Karya ilmiah merupakan kunci utama dalam penyelesaian masalah bagi user, karya ilmiah harus tetap memperhatikan norma dan etika bagi penulis, seperti tiga hal dalam etika ilmiah yakni harus menghindari fabrikasi, falsifikasi dan plagiarisme (IPB Press, 2012). Peneliti melakukan pengamatan secara cermat dan mengumpulkan data yang akan di ukur secara analitis dan tidak bias. Hal yang paling penting adalah karya ilmiah yang berdasarkan metode ilmiah yakni berdasarkan pada fakta, memiliki bukti objektif, memiliki analisis logis, menggunakan ukuran atau dapat diukur dan dapat dikuantifikasikan atau dapat dihitung 
(Fatihudin, 2012).

Karya ilmiah memiliki fungsi sebagai media untuk mengembangkan ilmu pengetahuan, teknologi, dan seni. Hal ini berkaitan dengan hakikat karya ilmiah yakni menyampaikan kebenaran melalui metode yang sistematis, metodologis dan konsisten (Lubis dan Rahimah, 2019:3). Berdasarkan fungsi tersebut, karya ilmiah dipandang sebagai cara untuk mencari jawaban atas masalah yang sedang dihadapi, terutama bagi mahasiswa sebagai peneliti muda yang akan menjadi generasi penerus bangsa untuk perkembangan ilmu pengetahuan. Maka karya ilmiah yang baik sering dijadikan sumber informasi ataupun sebagai bahan acuan bagi ilmuwan atau peneliti lainnya.

Masalah yang dihadapi oleh mahasiswa dalam proses penyusunan karya ilmiah adalah masih kurang pahamnya mahasiswa pada saat menulis karya ilmiah antara lain dalam pemilihan topic atau masalah, menentukan judul karya ilmiah, membuat introduction atau pendahuluan, serta referensi atau data-data yang diperlukan dalam penulisan karya ilmiah.

Berdasarkan beberapa masalah yang sering dihadapi oleh mahasiswa sebagai peneliti pemula dalam menyusun karya ilmiah, maka kami terdorong melakukan pengabdian kepada masyarakat dengan judul: Pelatihan Judul dan Introduction Dalam Karya Ilmiah Bagi Mahasiswa. Tujuan kegiatan pengabdian ini adalah untuk meningkatkan pengetahuan bagi para peserta pentingnya penulisan karya ilmiah serta untuk meningkatkan kemampuan para peserta dalam menentukan judul dan membuat introduction dengan baik dan benar sesuai pedoman penulisan karya ilmiah.

\section{Metode}

Kegiatan pengabdian ini dilakukan untuk meningkatkan pengetahuan dan pemahaman bagi para mahasiswa dalam menentukan judul karya ilmiah dan menyusun introduction atau pendahuluan didalam karya ilmiah berbentuk skripsi. Lembaga yang menangani kegiatan pengabdian ini adalah lembaga Pengabdian Masyarakat Universitas Negeri Gorontalo dalam rangka mewujudkan Tridharma Perguruan Tinggi. Khalayak sasaran dalam kegiatan pengabdian ini adalah mahasiswa di lingkungan Fakultas Ekonomi Khususnya Program Studi Akuntansi yang akan mengampu seminar usul proposal. berikut:

Metode yang digunakan dalam kegiatan pelatihan ini dapat digambarkan sebagai

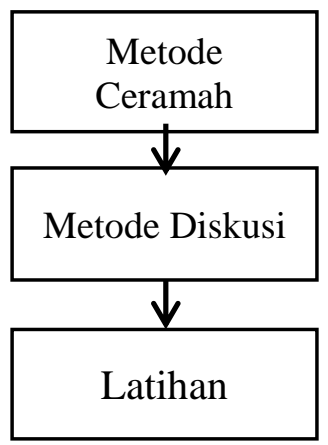

Gambar 1. Tahapan Metode Pengabdian 
a. Metode ceramah digunakan oleh pemateri unuk menjelaskan materi yang berkaian dengan cara penulisan judul dan introduction dalam karya ilmiah bagi mahasiswa.

b. Metode diskusi digunakan untuk memperdalam materi bahasan baik bentuk tanya jawab secara perorangan maupun perwakilan peserta.

c. Latihan digunakan untuk menulis judul dan menyusun pendahuluan bagi peserta secara offline.

Evaluasi dalam kegiatan ini dilaksanakan dalam tiga tahap yakni

1. Tahap perencanaan kegiatan. Pada awal kegiatan ini, pemateri menjelaskan tentang materi yang akan disampaikan.

2. Tahap selama proses kegiatan. Berdasarkan materi yang telah disampaikan peserta diberikan pelatihan penulisan judul dan introduction dalam karya ilmiah bagi mahasiswa .

3. Tahap akhir kegiatan. Evaluasi pada akhir kegiatan ini dilakukan untuk mengukur keberhasilan dari seluruh program pelatihan ini. Pada tahap ini pemateri melakukan evaluasi dari kegiatan dengan memberikan beberapa pertanyaan terkait materi yang telah disampaikan sebelumnya.

\section{Hasil}

Berdasarkan hasil observasi awal yang dilakukan dengan tatap muka bersama dengan para mahasiswa, ditemukan bahwa banyak mahasiswa yang masih sulit dalam melakukan pemilihan topik atau perumusan masalah pada saat menulis karya ilmiah. Padahal topik atau masalah menjadi fondasi utama sebuah karya ilmiah, tanpa adanya masalah maka sebuah karya ilmiah tidak akan menjadi sebagaimana mestinya. Selain sulit menentukan masalah, para mahasiswa juga masih kurang paham mengenai bagaimana seharusnya merumuskan judul, menulis pendahuluan (introduction), serta referensi-referensi atau data-data yang diperlukan dalam penulisan karya ilmiah.

Untuk mengatasi hal tersebut hal yang akan dilakukan adalah meningkatan pemahaman peserta pelatihan mengenai konsep dasar penyusunan karya ilmiah dengan memberikan tips dan langkah mudah dalam proses penentuan topik, perumusan judul, sampai pada penulisan introduction. Adapun beberapa langkah mudah dalam proses memilih topik penelitian yang menjadi dasar penyusunan karya ilmiah adalah sebagai berikut : brainstorming untuk ide, membaca informasi latar belakang umum, fokus pada topik, buat daftar kata kunci yang berguna, bersikap fleksibel, tentukan topik, sebagai pertanyaan penelitian yang berfokus, penelitian dan baca lebih lanjut tentang topik anda, merumuskan pernyataan. Judul memiliki sifat lebih spesifik ketimbang topik dan tema, perubahan dari tema ke judul cukup ditambahkan keterangan seperti tempat, waktu, metode, menerangkan kata dll. Sementara pendahuluan merupakan bagian pengantar penelitian. Pendahuluan berperan dalam mengantar pembaca untuk memahami alasan penelitian dilakukan, semakin jelas pendahuluan yang dibuat akan semakin membantu pembaca untuk memutuskan untuk perlu tidaknya penelitian dibaca lebih lanjut. 


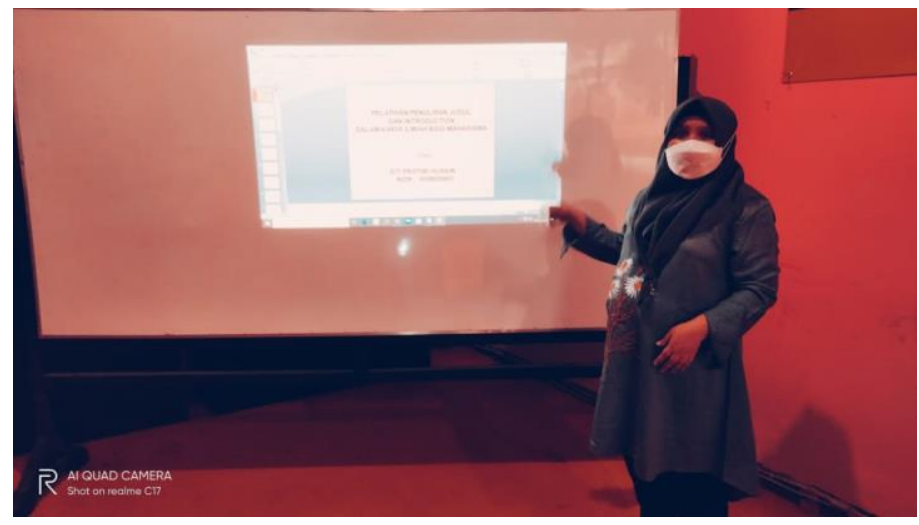

Gambar 2. Penjelasan materi oleh narasumber

Peserta pelatihan pada tahap awal (sesi I), diberikan materi tentang Karya Ilmiah. Sementara pada tahap kedua (sesi II) peserta diberikan materi karya ilmiah dan penjelasan mengenai bagaimana cara memilih topik dan menentukan judul serta menuliskan pendahuluan (introduction) yang baik dan benar. Setelah itu dilakukan sesi Tanya jawab terkait materi yang disampaikan. Terakhir dilakukan evaluasi untuk melihat sejauh mana keberhasilan program kegiatan pengabdian ini.

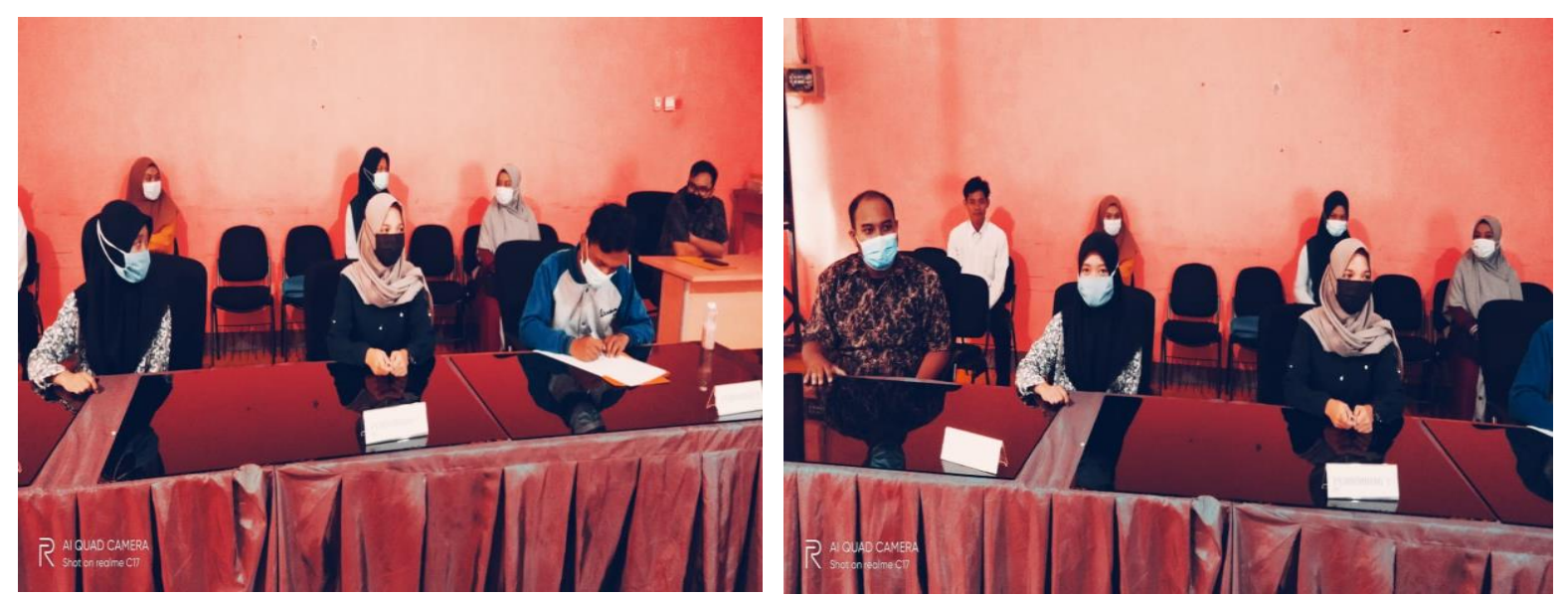

Gambar 3. Peserta pelatihan menerapkan physical distancing pada saat penerimaan materi

Berdasarkan hasil evaluasi diperoleh hasil bahwa sebagian besar peserta sudah memahami penjelasan materi yang disampaikan. Hal ini terlihat dari antusiasme peserta dan banyaknya pertanyaan yang diajukan oleh peserta terkait materi yang disampaikan.

\section{Diskusi}

Kegiatan pengabdian ini membawa risalah dalam meningkatkan pengetahuan dan pemahaman bagi para mahasiswa dalam menentukan judul karya ilmiah dan menyusun introduction atau pendahuluan di dalam karya ilmiah berbentuk skripsi. Diharapkan melalui kegiatan ini pengabdi dapat memberikan sumbangsih pemikiran mengenai ilmu dan keterampilan dalam menyusun sebuah karya ilmiah yang baik. Karya ilmiah menurut Susilo dalam Lubis dan Rahimah (2019:1) adalah karangan atau tulisan yang diperoleh sesuai sifat keilmuannya dan didasarkan oleh hasil pengamatan, pemantauan, penelitian dalam bidang tertentu, disusun menurut metode tertentu serta sistematika penulisannya bersantun bahasa dan isinya dapat dipertanggungjawabkan kebenarannya dan keilmiannya. Sedangkan menurut 
Lubis dan Rahimah (2019:1), karya ilmiah atau artikel ilmiah merupakan karya seorang ilmuwan yang hendak membangun ilmu pengetahuan, teknologi dan seni yang didapat melalui literature, pengalaman, serta penelitian. Judul yang akan diambil harus memiliki sifat lebih spesifik ketimbang Topik dan Tema. Perubahan Tema Ke Judul cukup ditambahkan keterangan seperti waktu, tempat, metode, dapat menerangkan makna kata, dan sebagainya. Jika Topik sudah ditentukan maka selanjutnya akan di buat Judul. Misalnya: topik : Kinerja Perusahaan, Maka Judul : Analisis Faktot-Faktor Yang Mempengaruhi Kinerja Perusahaan. Judul dapat menjelaskan manfaat bagi pembaca, dapat menarik pembaca karena judul dapat dipengaruhi oleh faktor "Kreativitas". Judul sebaiknya tidak lebih dari "12 kata" jika akan di publikasi dalam jurnal nasional dan tidak lebih dari "10 kata" apabila akan di publish dalam jurnal international. (Aminullah,2020). Menulis judul dapat dilakukan di awal penulisan naskah sebagai pedoman arah dalam menulis isi naskah karya ilmiah. Ada beberapa hal yang perlu diperhatikan ketika menyusun judul, antara lain:

1. Hindari ada kata sambung seperti untuk, yang, bagi kepada dan sebagainya.

2. Singkat

3. Cermin dari seluruh isi tulisan (arah, tujuan dan ruang lingkup)

Judul yang akan diambil harus memiliki sifat lebih spesifik ketimbang Topik dan Tema. Perubahan Tema Ke Judul cukup ditambahkan keterangan seperti waktu, tempat, metode, dapat menerangkan makna kata, dan sebagainya.

Jika Topik sudah ditentukan maka selanjutnya akan di buat Judul. Misalnya: topik : Kinerja Perusahaan, Maka Judul : Analisis Faktot-Faktor Yang Mempengaruhi Kinerja Perusahaan. Judul dapat menjelaskan manfaat bagi pembaca, dapat menarik pembaca karena judul dapat dipengaruhi oleh faktor "Kreativitas". Judul sebaiknya tidak lebih dari "12 kata" jika akan di publikasi dalam jurnal nasional dan tidak lebih dari "10 kata" apabila akan di publish dalam jurnal international. (Aminullah,2020)

Pendahuluan merupakan bagian pengantar karya ilmiah. Pendahuluan berperan dalam mengantar pembaca untuk memahami alasan penelitian dilakukan. Semakin jelas tidaknya pendahuluan yang dibuat penulis akan semakin membantu pembaca untuk memutuskan untuk perlu tidaknya penelitian dibaca lebih lanjut. Sedangkan dalam Latar Belakang akan memuat garis besar pemikiran yang mendasari penulisan karya ilmiah. Dalam membuat latar belakang, penulis dapat menggunakan Logika deduktif - induktif (Aminullah, 2020).

Paragraf Deduktif adalah jenis paragraf yang dimulai dengan penjabaran hal-hal umum terlebih dahulu dan selanjutnya ke hal khusus. Paragraf deduktif ini letak kalimat utama ada di awal kalimat dan di perinci dengan kalimat penjelas. Sedangkan paragraf Induktif adalah pagraf yang diawali dengan kalimat penjelas berupa fakta dan kalimat utama terletak di akhir kalimat dan pada pagraf induktif ini disertai generalisasi, analogi, sebab akibat dan perbandingan (Aminullah, 2020).

Secara umum pendahuluan mencangkup hal penting yang menjadi fokus peneliti membuat penelitian yang berbobot seperti yang dikemukakan oleh (Aminullah, 2020) dibawah ini :

1. Terdapat Fenomena dalam penelitian

2. Terdapat Research Gap, masalah pokok penelitian (untuk artikel)

3. Ada pandangan penelitian sebelunya dan pandangan penelti terhadap fenomena tersebut

4. Ada motivasi penelitian untuk mengkaji research gap dengan mempelajari teori dan penelitian sebelunya yang relevan ( secara umum dan singkat) 
5. Ada kontribusi penelitian (secara umum)

6. Mengapa penelitian ini penting dilakukan

7. Ada Novelti (originalitas penelitian)

Menurut Fatihudin (2012:119) Sub bab dalam pendahuluan terdiri dari latar belakang masalah, rumusan masalah, tujuan penulisan dan manfaat penulisan. Dalam latar belakang masalah (LBM) semua hal atau beberapa hal dari berbagai sudut pandang, ada kaitan, berkorelasi antar hal, dan apa saja yang menjadi alasan menulis atau mengkaji yang menjadi topik bahasan anda. Secara jelas dapat dicermati hal berikut ;

a. Apa alasan, mengapa menulis judul tersebut ?

b. Disinyalir adanya kesenjangan/masalah (berdiri sendiri/kompleks)

c. Memiliki pengaruh/akibat yang ditimbulkan pada aspek (sosial-budaya pendidikan-agamapertahanan-keamanan)

d. Gambaran kegunaan langsung atau tidak langsung dari hasil kajian

e. Memiliki kompleksitas permasalahan

Rumusan masalah menunjukkan masalah-masalah pokok yang sudah menjadi Pilihan utama penulis untuk dibahas dalam tulisan. Dari masalah yang begitu Kompleks maka dipilihlah masalah yang akan dicari jawabannya. Isi dan fungsi dari Rumusan masalah sebagai berikut:

a. Mengidentifikasi/merumuskan gejala/fenomena; mempunyai masalah atau tidak Memiliki kesenjangan antara satu hal dengan hal lainnya.

b. Pada umumnya berbentuk pertanyaan (Question)

c. Bisa juga dalam bentuk pernyataan (Statement)

d. Ada jarak antara harapan dengan kenyataan (Fatihudin, 2019:119)

Setiap kegiatan menulis hampir dipastikan memiliki tujuan. Maka sebaiknya dalam setiap tulisan, jangan lupa menyampaikan apa maksud dan tujuan membahas topik tersebut. Isi dan fungsi tujuan meliputi ;

a. Untuk apa tujuan menulis/mengkaji judul tersebut?

b. Tindak Lanjut dari masalah yg diidentifikasi.

c. Sikap/perlakuan yang hendak diambil dari adanya masalah yang diidentifikasi (Fatihudin, 2019:120)

Apakah tulisan anda ini memiliki manfaat langsung dan tidak langsung pada orang lain, lembaga lain, perusahaan, pemerintah, penelitian lanjut atau untuk lainnya. Tulislah manfaat dari tulisan anda tersebut dengan jelas.

a. Bermanfaat untuk siapa saja ?

b. Apa manfaat langsung atau tidak langsung dari kajian tersebut

c. Seberapa jauh hasil kajian memiliki manfaat/gunalaksana bagi siapa, pihakmana (perorangan, kelompok, institusi, negara)

d. Berkonstribusi pada ilmu pengetahuan atau kebijakan (Fatihudin, 2019:121)

Berdasarkan hasil pelaksanaan kegiatan pengabdian ini, para peserta akhirnya menemukan titik terang pada proses penyusunan karya ilmiah mereka. Mereka yang tadinya kebingungan untuk menentukan masalah, memilih topik dan judul penelitian, bagaimana memulai menulis introduction, akhirnya mampu menentukan bagaimana seharusnya mereka menentukan masalah, memilih topik dan judul penelitian serta menulis introduction yang tepat. Dengan adanya kegiatan pengabdian ini, para mahasiswa merasa sangat terbantu dalam proses 
penyelesaian skripsi mereka, karena skripsi yang baik dimulai dari topic \& masalah uptodate, judul yang baik dan pendahuluan atau latar belakang yang kuat.

\section{Kesimpulan}

Hasil kegiatan ini memberikan manfaat yang besar bagi para peserta pelatihan yang dalam hal ini adalah mahasiswa dalam proses pembuatan karya ilmiah mulai dari penentuan masalah, perumusan judul, penulisan pendahuluan (introduction) serta referensi dan data penelitian, sehingga karya ilmiah yang dihasilkan oleh para mahasiswa menjadi karya ilmiah yang berkualitas. Kegiatan pelatihan seperti ini perlu terus dilakukan karena memberikan manfaat bagi para peserta khususnya mahasiswa dalam menghasilkan karya ilmiah yang berkualitas yang dapat bersaing di event-event penulisan karya ilmiah nasional bahkan internasional. Selain itu setiap tahunnya mahasiswa diwajibkan mengontrak seminar usul penelitian sebagai langkah pertama dari rangkaian proses penyusunan skripsi, sehingga kegiatan seperti ini harus rutin dilakukan agar semua mahasiswa memiliki pemahaman mengenai penentuan masalah yang menjadi fondasi penelitian, perumusan judul penelitian serta penulisan introduction atau pendahuluan.

\section{Pengakuan/Acknowledgements}

Ucapan terima kasih yang tak terhingga penulis berikan kepada semua pihak yang telah berkontribusi atas terlaksananya kegiatan pengabdian ini. Terima kasih kepada bapak Dekan Fakultas Ekonomi Universitas Negeri Gorontalo yang telah memberikan izin dan rekomendasi bagi tim pengabdi melaksanakan kegiatan ini, terima kasih pula penulis ucapkan kepada Ketua Jurusan Akuntansi, Kaprodi, Sekretaris Jurusan beserta seluruh rekan dosen di Jurusan Akuntansi FE UNG yang senantiasa memberikan dukungan dan semangat dalam penyelesaian kegiatan pengabdian ini. Kepada tim pengabdi yang telah bersama-sama mensukseskan kegiatan pengabdian ini. Dan khususnya bagi mahasiswa peserta kegiatan yang telah bersedia untuk mengambil peranan penting dalam kegiatan ini.

\section{Daftar Referensi}

Assagaf, Aminullah. 2020. Penulisan Karya Ilmiah Lanjutan. Virtual Learning. By: Proaktif Akademisi.

Fatihudin, Didin.2012. Metode Penelitian \& Teknik Penulisan Karya Ilmiah Untuk Ilmu Ekonomi, Manajemen dan Akuntansi. Penerbit: PPs UM Surabaya

Lubis, Mina dan Rahimah, Anni. (2019). Kemampuan Menulis Karya Tulis Ilmiah Mahasiswa. Penerbit CV. Berkah Prima, Padang.

Kamayanti, A. (2016). Metodologi Penelitian Kualitatif Akuntansi. Jakarta Selatan: Yayasan Rumah Peneleh.

Kuswarno, E. (2009). Fenomenologi : metode penelitian komunikasi : konsepsi, pedoman, dan contoh penelitiannya. Bandung: Widya Padjajaran.

Moleong, L. (2016). Metodologi Penelitian Kualitatif. Bandung: PT. Remaja Rosdakarya 